\title{
PARAMETERS EXAMINATION OF A BIOSURFACTANT PRODUCTION AT LABORATORY SCALE
}

\author{
Neira-Gladys Rosero*1, Astrid-Lorely Pimienta*1, Fanny Dugarte ${ }^{2}$ and \\ Fredy-Gonzalo Carvajal ${ }^{3}$ \\ ${ }^{1}$ Ecopetrol S.A. - Instituto Colombiano del Petróleo, A.A. 4185 Bucaramanga, Santander, Colombia \\ ${ }^{2}$ Ambar S.A., Venezuela \\ ${ }^{3}$ Universidad Autónoma de Bucaramanga, Facultdad de Ingeniería en Energía, Bucaramanga, Santander, Colombia \\ e-mail:nrosero@ecopetrol.com.co e-mail:apimient@ecopetrol.com.co
}

(Received 22 May 2002; Accepted 4 November 2003)

his work presents the results obtained from the laboratory-scale experimentation for the optimization of production of rhamnolipid-type biosurfactant in a batch process, through the calculation and analysis of yield parameters. Different carbon/nitrogen ratios were studied, for which the production rates of rhamnolipid under nitrogen limitation was defined. Bacterial growth yield parameters $Y_{X / N}$ and $Y_{X / C}$, were also calculated.

Este trabajo presenta resultados de la fase de laboratorio, correspondientes a la optimización del proceso de producción de un biosurfactactante tipo ramnolípido, mediante la obtención y análisis de sus parámetros de rendimiento. Se estudiaron diferentes relaciones carbono/nitrógeno determinando la velocidad de producción de ramnolípido en condiciones de limitación por nitrógeno. También se estimaron los parámetros de rendimiento del crecimiento bacteriano $Y_{X / N}$ y $Y_{X / C}$, logrados con los substratos de nitrógeno y carbono.

Keywords: rhamnolipid, biosurfactant, nitrogen limitation, yield parameters.

* To whom correspondence may be addressed 


\section{INTRODUCTION}

Surface-activity substances (surfactants) are widely used in the oil industry. Application of such substances include tank-bottom cleaning processes, bioremediation, and enhanced recovery, among others. Until a few years ago, the additives selection criteria focused on their efficiency and cost. However, given the urgent and increasing need of protecting the environment, biodegradability has currently become the main criterion for the selection of additives, especially when spillages may not be avoided (Lang and Wullbrandt, 1999; Bognolo, 1999; Banat, 1995; Fiechter, 1992; Díaz, 1991).

Ecological and technical advantages provided by biosurfactants are not significant enough to drive a process design at industrial levels; therefore, efforts have focused on the achievement of their financial competitiveness against synthetic surfactants. Excluding genetic enhancements (due to their high costs), other factors that should be considered for cost reduction purposes include bacterial functional stability and reproductiveness; optimization of carbon sources and micronutrients concentration and nature; and, energetic cost reductions in stirring and aeration efforts (Rosero et al., 2000).

As a requirement for rhamnolipid accumulation, a mechanism called quorum sensing is activated whenever nitrogen deficiencies are defined (Pearson et al., 1995). This condition is achieved when the formulation of culture is nitrogen limitation-driven (Venkata and Karanth, 1989; Brennan et al., 1970 in Kosaric, 1993). In continuous production systems, nitrogen concentrations are reduced in the feeding medium, in order to enhance biosurfactant overproduction (Gruber et al., 1993 in Kosaric, 1993). In addition, the type of nitrogen source has an effect on this process; therefore, sources such as nitrate, ammonia, urea and amino acids have been tested, among others (Mulligan and Gibbs, 1989).

Nitrogen concentration is relevant for the definition of an optimal biomass concentration, while the concentration of hydrophobic carbon source defines the conversion of available carbon into biosurfactant (Hommel et al., 1987; Kosaric, 1993). Limitation of multivalent cations, such as iron (+2), magnesium or calcium, also increases rhamnolipid production rates (Syldatk et al., 1984 in Kosaric et al., 1987; Itoh and Suzuki, 1974, and Guerra-Santos et al., 1986).

Various soluble and insoluble carbon sources have been assessed for biosurfactant production, using Pseudomonas aeruginosa. Glucose (Guerra-Santos et al., 1984; Robert et al., 1989; Sundari and Sandhya, 1995; Mulligan and Gibbs, 1989; Pimienta et al., 1997), propyleneglycol and glycerol (Oschner et al., 1996; Fiechter, 1992; Pimienta et al., 1997) have been used as the main soluble sources, while hexadecane (Montes de Oca, 1992), oleic acid (Banat et al., 1991) vegetable oil (Oschner et al., 1996; Fiechter, 1992; Linhardt et al., 1989; Pimienta et al., 1997), olive oil (Mercadé et al., 1993), polycyclic aromatic hydrocarbons (Déziel et al., 1996), paraffin (Montes de Oca, 1992; Pimienta et al., 1997), octadecane (Zhang and Miller, 1992), and differently-sourced crude oils (Sundari and Sandhya, 1995; Jain et al., 1992; MacElwee et al., 1990) have been used as the main insoluble sources.

This survey is part of the pilot project for the development of a production process for a biosurfactant called Tensobiol-ICP. It includes results for the initial stages of design and kinetic assessment of the culture's medium, as well as for the definition of the yield parameters. Further experiments, as based on these results, supported a significant reduction in related production costs (Rosero et al., 2000).

\section{METHODOLOGY}

\section{Microorganism}

Pseudomonas aeruginosa ICP70 strain, which was isolated from oily sludge and as included in the strain collection of the Biotechnology Laboratory at the Instituto Colombiano del Petróleo (ICP).

\section{Inocula preparation}

For each inoculum, a vial (cryo-preserved at $193 \mathrm{~K}$ ) was taken and successively passed twice through a nutritive broth, and twice through the production saline medium, in 24-hour intervals. 


\section{Culture conditions}

The medium consisted of (per $\mathrm{dm}^{-3}$ of drinking water): Glycerol, 30,5 $\mathrm{cm}^{3} ; \mathrm{MgSO}_{4}, 0,1 \mathrm{~g} ; \mathrm{K}_{2} \mathrm{HPO}_{4}, 7 \mathrm{~g}$; $\mathrm{KH}_{2} \mathrm{PO}_{4}, 3 \mathrm{~g}$; $\left(\mathrm{NH}_{4}\right)_{2} \mathrm{SO}_{4}, \mathrm{pH} 6,5-7,0$; variable as per $\mathrm{C} / \mathrm{N}$ ratio.

Different $\mathrm{C} / \mathrm{N}$ ratios were evaluated (20, 40, 60, 80 and 100) keeping above mentioned glycerol concentration, while the ammonia sulfate concentrations were respectively: $3 ; 1,5 ; 1 ; 0,75$ and 0,6 g. $\mathrm{dm}^{-3}$.

For the $\mathrm{C} / \mathrm{N}$ ratio of 20 it was made a second evaluation, using $1 \mathrm{~g} . \mathrm{dm}^{-3}$ of $\mathrm{K}_{2} \mathrm{HPO}_{4}$ and controlling the $\mathrm{pH}$ with a $1 \mathrm{~N}$ sodium hydroxide solution.

\section{Operating conditions}

$2 \mathrm{dm}^{3}$ Erlenmeyer flasks with $3 \mathrm{~cm}$ deep baffles were used. The following conditions were used: work volumes of $800 \mathrm{~cm}^{3}$, temperature of $305 \mathrm{~K}$, and orbital stirring of $140 \mathrm{rpm} . \mathrm{pH}$ value verifications were performed during the fermentation process.

\section{Microbiological follow-up}

The dry weight technique was used to quantify microbial growth (Madigan et al., 1997) as bacterial density, through the culture's absorbance at $540 \mathrm{~nm}$. Controls on the media were processed in parallel, in order to eliminate any interference due to the presence of suspended solids.

\section{Rhamnolipid quantification}

Rhamnolipid quantification was performed through the measurement of rhamnose via the thioglycolic acid method (Whistler and Wolfrom, 1962).

Calculation of the RL concentration was made as follows (Rosero et al., 2000):

$\left[\mathrm{RL}_{\mathrm{ppm}}\right]=1,8^{*}(54,18 \times$ Absorbance $(400-430)-1,497) \mathrm{x}$ dilution factor

The equipment used for this analytical method, as well as for the other spectrofotometrical procedures was the spectrophotometer UV-VIS CARY 1E VARIAN.

\section{Glycerol determination.}

Glycerol quantification was carried out via colorimetry with cupric chloride, as per the method described by Whistler and Wolfrom, (1962).

\section{Nitrogen determination. nessler method}

Measurement of ammoniacal Nitrogen was performed via a method based on Nessler's colorimetric technique (APHA, 1992). Corresponding results are stated as ammoniacal nitrogen $\left(\mathrm{mg} \mathrm{N}-\mathrm{NH}_{3} / \mathrm{dm}^{-3}\right)$.

\section{pH-measurement}

Measurement of $\mathrm{pH}$ was carried out with the potentiometric analyzer ORION Model 720A, using the same samples which had been taken for rhamnolipid and nitrogen determinations.

\section{Yield factors}

The following formula was used to calculate nitrogen and glycerol yields for biomass production:

$$
Y_{x / s}=\frac{\sum(d x / d t) / n}{\sum(d S / d t) / n}
$$

Where:

$x$ : Concentration of biomass or generated product (biomass, biosurfactant)

$d S$ : Delta value for substrate consumption (nitrogen, glycerol)

$d t$ : Delta value for process hours

$n$ : Number of measurements taken during the exponential growth interval

Each assay and measure was assessed threefold to guarantee the reproducibility of the results.

\section{RESULTS AND DISCUSSION}

Figure 1 shows the biomass concentration variation versus time, for all the different $\mathrm{C} / \mathrm{N}$ ratios experimented. The highest and lowest concentrations of biomass were observed for $\mathrm{C} / \mathrm{N}$ ratios of 20 and 100 , respectively. This implies that all ingredients, except for nitrogen, were supplied in quantities enough to support bacterial growth, since growth values were limited by the nitrogenous content.

For $\mathrm{C} / \mathrm{N}$ ratios ranging from 40 to 100 , the medium's $\mathrm{pH}$ control was maintained between 6,2 and 7,0, due 


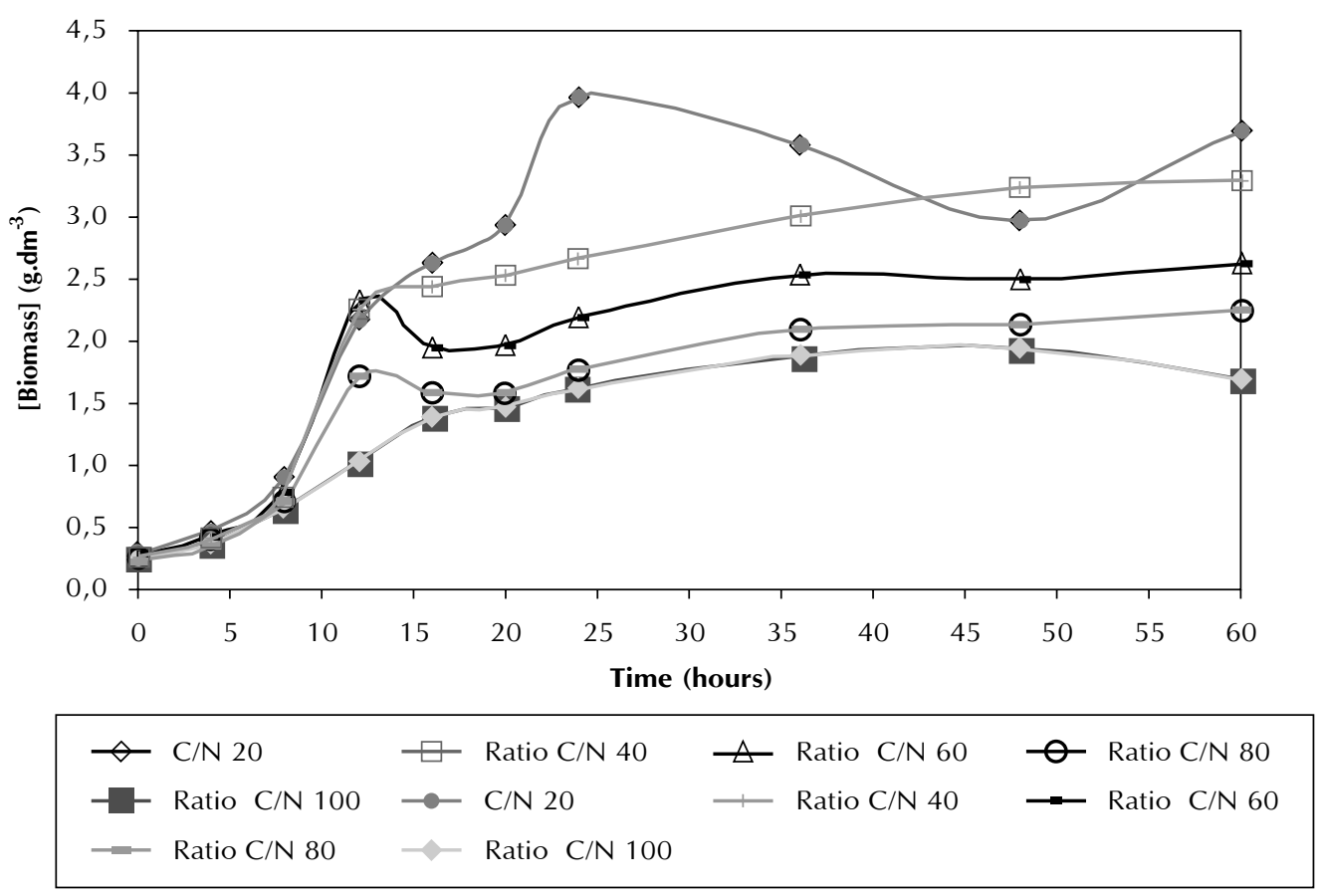

Figure 1. Growth kinetics of Pseudomonas aeruginosa ICP 70 with glycerol as carbon source at different $\mathrm{C} / \mathrm{N}$ ratios. Process time: 60 hours; volume: $800 \mathrm{~cm}^{3}$; temperature $305 \mathrm{~K}$; $140 \mathrm{rpm}$; $\mathrm{pH} 7$; commercial grade medium

to phosphate salts being present (data not displayed). However, for the $\mathrm{C} / \mathrm{N}$ ratio of $20, \mathrm{pH}$ values below 6,0 were observed after 20 hours, and values below 5,0 were observed after 60 hours of processing (Figure 2). For $\mathrm{C} / \mathrm{N}$ ratio of 20 the phosphate contents used in the culture broth was not enough to control a higher quantity of acids released into the medium as a result of the microbial activity of a higher biomass concentration produced.

Figure 3 indicates that for the same $\mathrm{C} / \mathrm{N}$ ratio of 20, it is observed that deficiency of $\mathrm{pH}$ control affected the activity of enzymes and therefore the amount of nitrogen consumption. It also shows that the biosurfactant is mainly produced during the stationary phase.

Rhamnolipid production rate was calculated for the stationary phase (16 to 60 hour of processing). The highest production rate was observed for the $\mathrm{C} / \mathrm{N}$ ratio of $40\left(45 \mathrm{mg} \cdot \mathrm{dm}^{-3} \cdot \mathrm{h}^{-1}\right)$, followed by the ratio of $60\left(33,12 \mathrm{mg} \cdot \mathrm{dm}^{-3} \mathrm{~h}^{-1}\right)$, the ratio of $80\left(25 \mathrm{mg} \cdot \mathrm{dm}^{-3} \mathrm{~h}^{-1}\right)$, and the ratio of $100\left(19,8 \mathrm{mg} \cdot \mathrm{dm}^{-3} \mathrm{~h}^{-1}\right)$.

For the $\mathrm{C} / \mathrm{N}$ ratio of 20 , production rate obtained for the 12 to 20 hour term was of $54 \mathrm{mg} \cdot \mathrm{dm}^{-3} \mathrm{~h}^{-1}$; however, a sharp reduction in rhamnolipid productivity was observed, after 20 hour related with the medium's acidity. When the $\mathrm{C} / \mathrm{N}$ ratio of 20 was tested, while using $\mathrm{pH}$ control with $1 \mathrm{~N} \mathrm{NaOH}$, the biosurfactant's productivity for the 24 to 72 hour was of $52 \mathrm{mg} . \mathrm{dm}^{-}$ ${ }^{3} \mathrm{~h}^{-1}$ (data not displayed). During the stationary phase, eventhough the net growth rate is zero, cells are still metabolically active and their performance depends on cell density, as well as on $\mathrm{pH}$ and available carbon content.

Figure 4 shows specific growth rate, defined for each $\mathrm{C} / \mathrm{N}$ ratio, from the fourth to the sixteenth hour term, (that is, the exponential growth phase). For these conditions can be expected that cellular metabolic control system is set to achieve maximum rates of biomass production. The highest specific growth speed was observed for $\mathrm{C} / \mathrm{N}$ ratios of 40 and $60\left(0,21 \mathrm{~h}^{-1}\right)$.

Furthermore, to quantify in-biomass nitrogen and carbon yield factors $\left(\mathrm{Y}_{\mathrm{x} / \mathrm{N}}, \mathrm{Y}_{\mathrm{x} / \mathrm{C}}\right)$, the data used on bacterial concentrations and nutrients were the ones measured for the exponential growth phase in assessments on $\mathrm{C} / \mathrm{N}$ ratios of 40 and 20 , while $\mathrm{pH}$ was kept above 


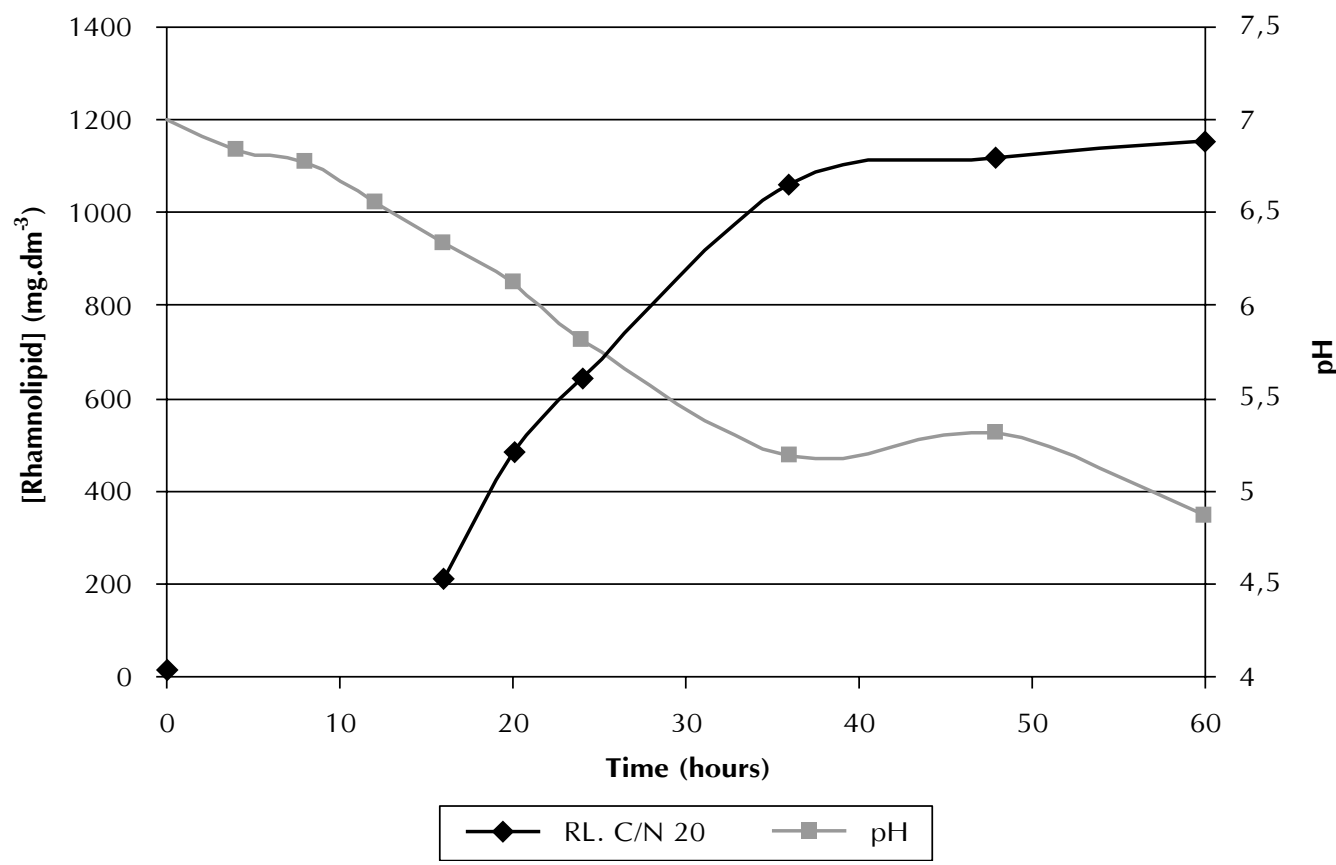

Figure 2. Effects of $\mathrm{C} / \mathrm{N}: 20$ of the rhamnolipid concentration and $\mathrm{pH}$ 's changes of Pseudomonas aeruginosa ICP 70 with glycerol as carbon source. Process time: 60 hours; volume: $800 \mathrm{~cm}^{3}$; temperature $305 \mathrm{~K}$; $140 \mathrm{rpm}$; pH 7; commercial grade medium

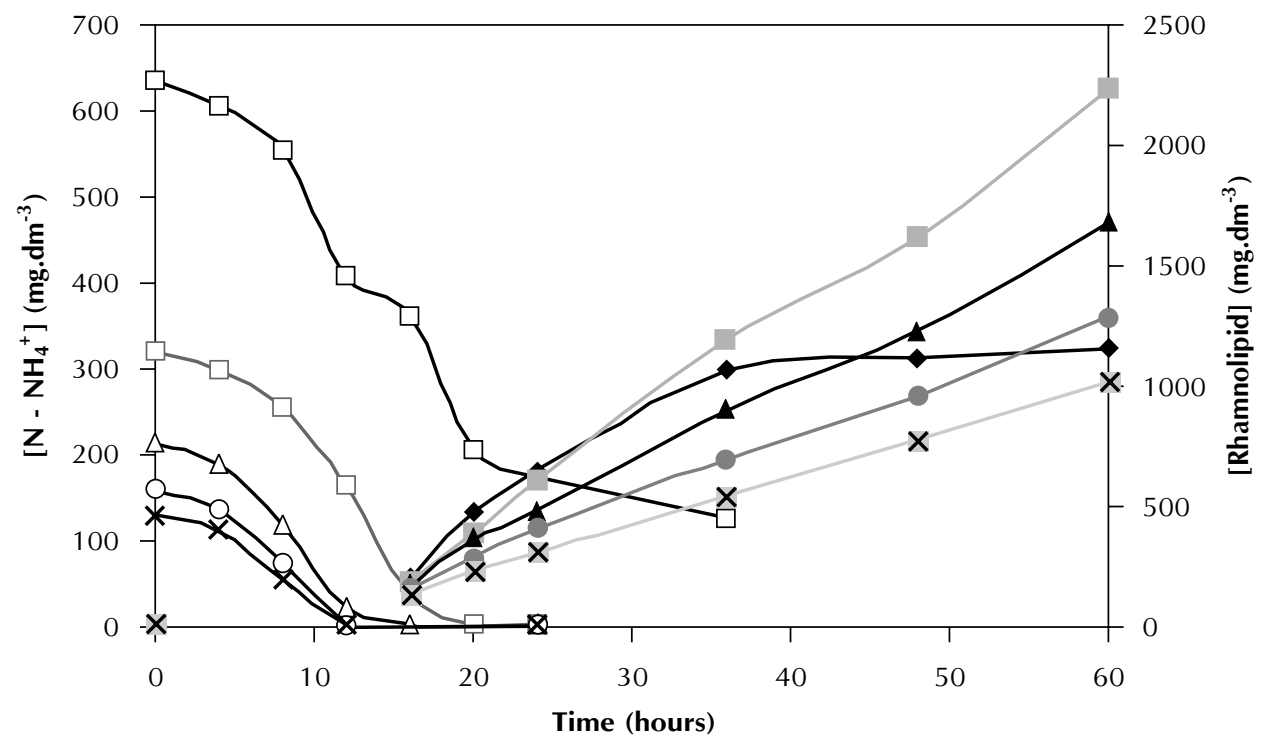

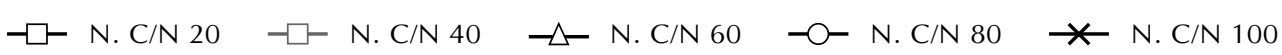

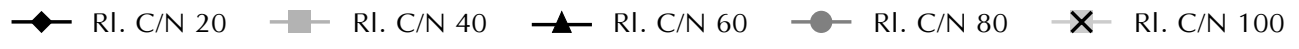

Figure 3. Productivity evaluation of rhamnolipid and nitrogen consumption of Pseudomonas aeruginosa ICP 70 with glycerol as carbon source to different $C / N$ ratios. Process time: 60 hours; volume: $800 \mathrm{~cm}^{3}$; temperature $305 \mathrm{~K}$; $140 \mathrm{rpm}$; pH 7; commercial grade medium 


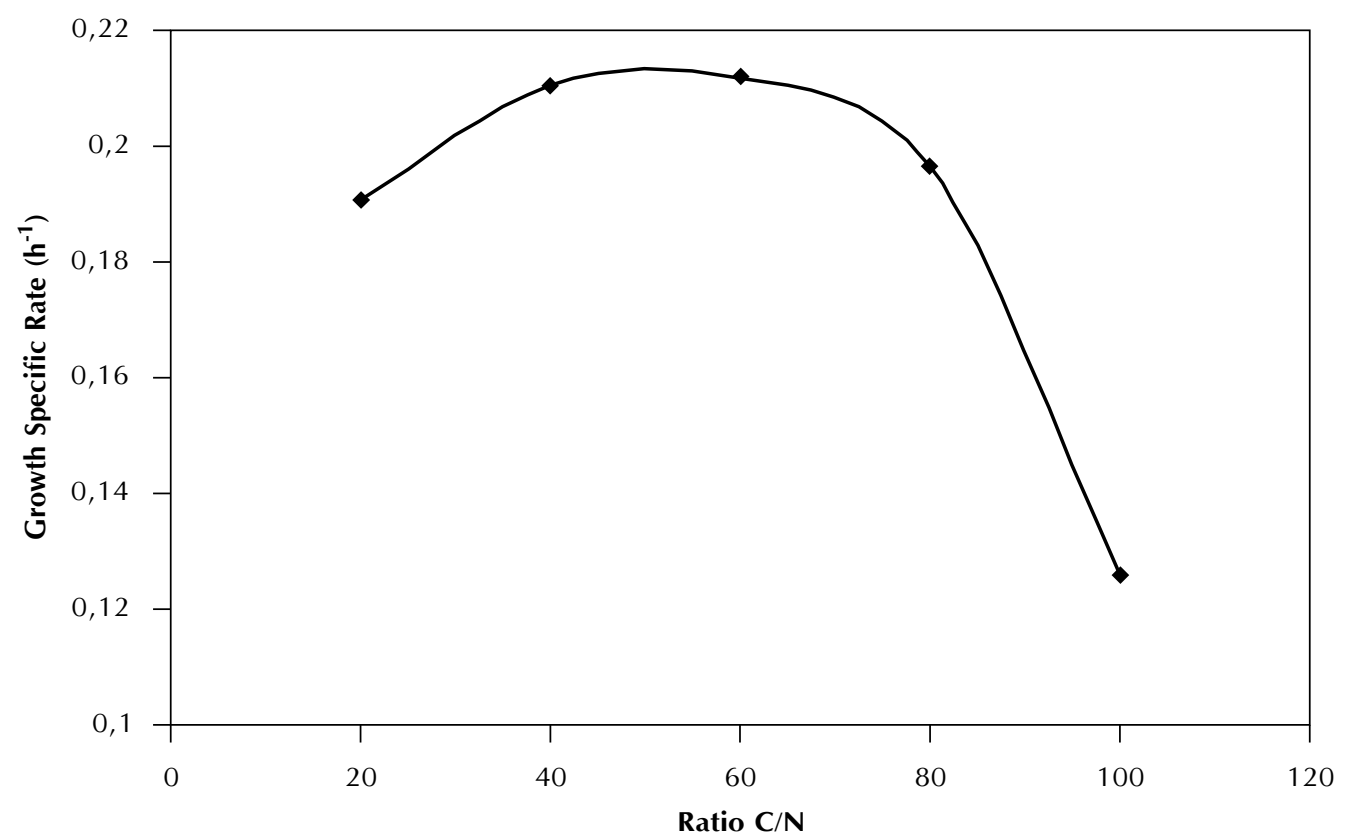

Figure 4. Growth specific velocity of Pseudomonas aeruginosa ICP 70 with glycerol as carbon source to different $\mathrm{C} / \mathrm{N}$ ratios. Process time: 60 hours; volume: $800 \mathrm{~cm}^{3}$; temperature $305 \mathrm{~K}$; $140 \mathrm{rpm}$; pH 7; commercial grade medium

6,0. Related calculations showed a variation coefficient under $12 \%$; as a result, the following was established:

$\mathrm{Y}_{\mathrm{x} / \mathrm{N}}$ is $6,5 \mathrm{~g}$ of biomass per gram Nitrogen

$\mathrm{Y}_{\mathrm{x} / \mathrm{Glyc}}$ is $0,26 \mathrm{~g}$ of biomass per gram Glycerol

Based on these values is possible to define the medium contents for higher cell densities, keeping in mind the use of feeding strategies to avoid inhibitory concentrations of nutrients.

\section{CONCLUSIONS}

- The experiments carried out using different carbon/ nitrogen ratios showed that nitrogen depletion induces rhamnolipid-type biosurfactant production, and that biosurfactant production rate is proportional to the bacterial density achieved at fermentation. It was found that the $\mathrm{pH}$ and carbon content provided during the stationary phase may improve productivity rhamnolipid rate and keep for a longer period of time the biomass activity.
Biomass apparent yield factors found for the nitrogen and glycerol substrates, support the quantification of the nutritional requirements by the microorganism discussed herein, under the fermentation conditions used. Based on these factors, it is possible to design culture media that would support higher bacterial concentrations, and compare efficiency of different sources for these ingredients.

- As part of the process design stage at a pilot scale level should be taken into consideration parameters such as aeration, stirring patterns, $\mathrm{pH}$ control, and feeding strategies for the achievement of high and metabolically active biomass to get optimal production of biosurfactant.

\section{ACKNOWLEDGEMENTS}

The authors wish to state their gratitude to Sandra Alvarez, for their invaluable cooperation in the development of this survey. 


\section{BIBLIOGRAPHY}

APHA, AWWA, WEF, 1992. "Standard methods for the examination of water and wastewater". APHA. $18^{\mathrm{a}} \mathrm{Ed}$. 4-75 - 4-80, USA.

Banat, I. M., 1995. "Biosurfactants production and possible uses in microbial enhanced oil recovery and oil pollution remediation”. Elsevier, Bioresource Technology, 51: 1-12.

Banat, I. M., Samarah, N., Murad, M., Horne, R. and Banerjee, S., 1991. "Biosurfactant production and use in oil tank clean-up". World J. Microbiol \& Biotech, 7: 80-88.

Brennan, P. J., Lehane, D. P. and Thomas, D. W., 1970. In: "Biosurfactants. Production-Properties-Applications". Eur. J. Biochem., 13:117. Surfactant Science Series, Vol. 48, Kosaric, N. (Ed.), 1993, Marcel Dekker, Inc., New York, USA, 483pp.

Bognolo, G., 1999. "Biosurfactants as emulsifying agents for hydorcarbons". Elsevier, Colloids Surfaces, A: Physicochem. Eng. Aspects, 152: 41-52.

Déziel, E., Paquette, G., Villemur, R., Lépine, F. and Bisaillon J., 1996. "Biosurfactant production by a soil pseudomonas strain growing on polycyclic aromatic hydrocarbons". Appl. Environ. Microbiol., 62: 1908-1912.

Díaz, M. P., 1991. "Estudio preliminar de la aplicación de biosurfactantes en el manejo de crudos pesados". Tesis de Maestría Fac. Ingeniería Química. Universidad Industrial de Santander, Bucaramanga, 168 pp.

Fiechter, A., 1992. "Biosurfactants, moving toward industrial application”. Tibtech, Vol. 10: 208-217.

Gruber, T., Chmiel, H., Käpelli, O., Sticher, P. and Fiechter, A., 1993. "Integrated process for continous rhamnolipid biosynthesis". In: "Biosurfactants. Production-Properties - Applications”. Surfactant Science Series, Vol. 48, Kosaric, N. (Ed.), 1993. Marcel Dekker, Inc., New York, USA, 483pp.

Guerra-Santos, L. H., Käppelli O. and Fietcher, A., 1984. "Pseudomonas aeruginosa biosurfactant production in continuous culture with glucose as carbon source". Appl. Environ. Microbiol., 48: 301-305.

Guerra-Santos, L. H., Käppeli, O. and Fietcher, A., 1986. "Dependence of pseudomonas aeruginosa continuous culture biosurfactant production on nutritional and environmental factors". Appl. Microbiol. Biotechnol., 24: 443-448.

Hauser, G. and Karnovski, M. L., 1954. "Studies on the production of glycolipide by pseudomonas aeruginosa". Biotechnol., 68: 645-654.

Hommel, R., Stuwer, O., Stuber, W., Haferburg, D. and Kleber, H. P., 1987. "Biosurfactants. production - properties - applications". In: Surfactant Science Series, Appl. Microbiol. Biotechnol., 26:199, Vol. 48, Kosaric, N. (Ed.), 1993. Marcel Dekker, Inc., New York, USA, 483pp.

Itoh, S. and Suzuki, T., 1974. "Fructose-lipids of arthrobacter, corynebacteria, nocardia and mycobacteria grown on fructose". Agr. Biol. Chem., 38: 1443-1449.

Jain, D. K., Lee, H. and Trevors, J., 1992. "Effect of addition of pseudomonas aeruginosa UG2 inocula or biosurfactants on biodegradation of selected hydrocarbons in soil". $J$. Industri. Microbiol., 10: 87-93.

Kosaric, N. (Ed.), 1993. "Biosurfactants. Production - Properties - Applications”. Surfactant Science Series, Vol. 48. Marcel Dekker, Inc., New York, USA, 483pp.

Kosaric, N., Cairns, W. L. and Gray, N. C. C. (Eds.), 1987. "Biosurfactants and biotechnology". Surfactant Science Series, Vol. 25, Marcel Dekker, Inc., New York, USA, 342pp.

Lang, S. and Wullbrandt, D., 1999. "Rhamnose lipids - biosynthesis, microbial production and aplication potential". Appl. Microbiol. Biotechnol., 51: 22-32.

Linhardt, R. J., Bakhit, R., Daniels, L., Mayerl, F. and Pickenhagen, W., 1989. "Microbially produced rhamnolipid as a source of rhamnose". Biotechnology Bioeng., 33: 365-368.

MacElwee, C. G., Lee, H. and Trevors, J., 1990. "Production of extracellular emulsifying agent by pseudomonas aeruginosa UG1". J. Industri. Microbiol., 5: 25-32.

Madigan, M. T., Martinko, J. M. and Parker, J., 1997. “Brock biology of microorganisms". Prentice Hall, New Jersey, USA, 986pp.

Mercadé, M. E., Manresa, M. A., Robert, M., Espuny, M. J., De Andrés, C. and Guinea, J., 1993. “Olive Oil Mill Effluent (OOME) new substrate for biosurfactant production”. Bioresource Technology, 43: 1-6. 
Mulligan, C. N. and Gibbs, B. F., 1989. "Correlation of nitrogen metabolism with biosurfactant production by pseudomonas aeruginosa". Appl. Environ. Microbiol., 55: 3016-3019.

Montes de Oca, G. M. A., 1992. "Producción de biosurfactantes microbianos". Revista del Instituto Mexicano del Petróleo, 24(4): 68-72.

Oschner, U., Hembach, T. and Fiechter, A., 1996. "Production of Ramnolipid Biosurfactants". In: Advances in Biochemical Engineering Biotechnology, Vol. 53, Fiechter, A. (Ed.), Springer, Berlin Heidelberg, New York.

Pearson, J. P., Passador, L., Iglewski, B. H. and Greenberg, E. P., 1995. "A second $N$-acylhomoserine lactone signal produced by pseudomonas aeruginosa". Proc. Natl. Acad. Sci., USA, 92: 1490-1494.

Pimienta, A. L., Díaz, M. P., Carvajal, F. G. and Grosso, J. L., 1997. "Production of biosurfactants (Rhamnolipids) by pseudomonas aeruginosa isolated from colombian sludges". CT\&F - Ciencia, Tecnología \& Futuro, 1 (3): 95-108.

Robert, M., Mercadé, H., Bosch, P., Parra, J. L., Espuny, M. J., Manresa, M. A. and Guinea, J., 1989. "Effect of the carbon source on biosurfactant production by pseudomonas aeruginosa 44T1". Biotechnol. Lett., 11: 871-874.

Rosero, N. G., Pimienta, A. L., Dugarte, F, Carvajal, F. G., Nieto, L. P. and Alvarez, S., 2000. "Producción de biosurfactantes". Informe Técnico de Avance Ecopetrol-ICP.

Sundari, R. B. T. and Sandhya, S., 1995. "Extracellular microbial lipids from psedudomonas $\mathrm{S}_{\mathrm{p}} \mathrm{Ls}_{1} \mathrm{AS}$ bioemulsifiers". J. Environ. SCI. Health, 171-182.

Syldatk, C., Malutovic, H. and Wagner, F., 1984. "Biotech Forum". In: Biosurfactants and Biotechnology. Surfactant Science Series, Vol. 25, 1: 53. Kosaric, N., Cairns, W. L. and Gray, N. C. C. (Eds.), 1987, Marcel Dekker, Inc., New York, USA, 342pp.

Venkata Ramana, K. and Karanth, N. G., 1989. "Factors affecting biosurfactant producing using pseudomonas aeruginosa CFTR-6 under submerged conditions". $J$. Chem. Tech. Biotech., 45: 249-257.

Whistler, R. and Wolfrom, M., 1962. "Methods in Carbohydrate Chemistry”. Vol. 1, Academic Press, New York.

Zhang, Y. and Miller, R., 1992. "Enhanced octadecan dispersion and diodegradation by a pseudomonas rhamnolipid surfactant (Biosurfactant)". Appl. Environ. Microbiol., 58: 3276-3282. 